UDC 340.12

DOI https: / / doi.org/10.32837 / yuv.v0i5.2007

V. Horielova,

Candidate of Legal Sciences,

Associate Professor at the Department of State Legal Sciences

"KROK" University

\title{
PUBLIC MORALITY AS AN OBJECT OF NATIONAL SECURITY OF UKRAINE: THEORETICAL AND LEGAL ASPECT
}

Human life has always been based on certain values on the basis of which the ideas of human rights and freedoms have been nurtured for centuries. Moral values are, first of all, a set of principles, ideas, views of one person and society as a whole. The formation of morality occurs throughout the existence of human civilization, but the phenomenon of morality, is that despite the constant evolutionary changes taking place in society, the basic moral values remain almost unchanged. This is primarily due to the fact that concepts such as "good" and "evil" will always be the centre of attention and the lever of all problems. Public morality cannot be "programmed" even by interpreting the practice of past world experience, because even prominent thinkers of the past (I. Kant) defined morality as a "self-legislative" human principle, which reflects the inner will and desire of every intelligent being. This inner will and moral desire is a duty associated with the law, and laws are established in accordance with the purpose of nature, because man seeks to be subject only to their desires that are consistent with their own will [1, p. 46]. Also, it is believed that morality belongs to the social sphere (Hegel) and a person's morality is determined by his actions, which reflect his way of life, which is aimed at subordination to the interests [2, p. 47]. Thus, moral values are always more appropriate to lay in the legal field to be protected. after all, a person seeks to be subject only to their desires that are consistent with their own will [1, p. 46]. In addition, it is believed that morality belongs to the social sphere (Hegel) and a person's morality is determined by his actions, which reflect his way of life, which is aimed at subordination to the interests [2, p. 47]. Thus, moral values are always more appropriate to lay in the legal field to be protected. after all, a person seeks to be subject only to their desires that are consistent with their own will [1, p. 46]. Also, it is believed that morality belongs to the social sphere (Hegel) and a person's morality is determined by his actions, which reflect his personal way of life, which is aimed at subordination to the interests [2, p. 47]. Thus, moral values are always more appropriate to lay in the legal field to be protected.

The level of public morality in fact clearly projects the state of democracy and stability of this society. At the same time, morality, as an object, is a measure of a person's freedom and determines the protection of his rights and freedoms, harmonizes his individual interests with public ones. Being a socially significant object, morality corrects the behaviour of officials of state bodies, promotes the proper performance of their duties, enables the responsibility of the latter and prevents arbitrariness. 
Morality in a state governed by the rule of law will always be a means of regulating social relations, the ground for rooting values and the foundation of rules of conduct. In recent times, there has been a total decline in morality around the world, which harms all spheres of public life. Yes, in almost the works of all researchers can be seen the emphasis on the spiritual decline of society (society without God). Some scholars even point to the danger of a state of "morally ill society" in which ideals are distorted and become a source of thought about the absurdity of the world and suicide, and things become the meaning of life and dominate man [3, p. 366-370], that is, the dead rule over the living and the meaning of life and love is lost. After all, today a person adheres to everything artificial, sees no point in their own moral development and thus devalues their own lives, claiming false,

The current legislation of Ukraine is designed to ensure the protection of human rights and freedoms, but the special Law of Ukraine "On Protection of Public Morality" establishes only the legal basis for the protection of society from the distribution of products that adversely affect public morality [4]. At the same time, there are no interpretations of the concept of "morality" and "public morality" in this law. According to Art. 15 of this Law, control in the field of protection of public morals within its competence is carried out by the Ministry of Internal Affairs of Ukraine, National Police, central executive body implementing state policy in the field of culture, central executive body implementing state policy in cinematography, central the body of executive power that implements the state tax policy, the central body of executive power that implements the state customs policy, State Committee for Television and Radio Broadcasting of Ukraine and the National Council of Ukraine for Television and Radio Broadcasting.
In addition, there is also public control over compliance with the law in the field of protection of public morality, which is carried out by creative unions operating in the field of culture and arts, journalism. It is also important that under the Law of Ukraine "On Protection of Public Morality" (Article 15) the state undertakes to provide financial support for public control over compliance with legislation in the field of protection of public morality in the manner prescribed by the Cabinet Ministers of Ukraine. There is also a public control over compliance with the requirements of the legislation in the field of protection of public morality, which is carried out by creative unions operating in the field of culture and arts, journalism. It is also important that in accordance with the Law of Ukraine "On Protection of Public Morality" (Article 15) the state undertakes to provide financial support for public control over compliance with legislation in the field of protection of public morality in the manner prescribed by the Cabinet Ministers of Ukraine. There is also a public control over compliance with the requirements of the legislation in the field of protection of public morality, which is carried out by creative unions operating in the field of culture and arts, journalism. It is also important that in accordance with the Law of Ukraine "On Protection of Public Morality" (Article 15) the state undertakes to provide financial support for public control over compliance with legislation in the field of protection of public morality in the manner prescribed by the Cabinet Ministers of Ukraine.

In our opinion, the duty to respect the law in a state governed by the rule of law is based on the formula of the universality of the law of human nature, and although everyone can understand good and evil, useful and harmful, it is also subject to its own ideas of good and bad. Within the framework of the law, the basic scope of responsibilities, the standard of moral 
behaviour necessary for the normal functioning of the whole society is created. Thus, although the law cannot express the will of everyone and cannot correspond to the moral idea of justice of everyone, because the law is not a bunch of morality in the strict sense of the word, but in democratic, legal states it is through law that a person's personal space is created. she lives according to her own considerations of morality.

The importance of morality today is recognized at all levels of government. The President of Ukraine, first of all, noted that the moral values of the citizens of Ukraine should become one of the objects of national security. The relevant amendment to the Law of Ukraine "On the Security Service of Ukraine" was submitted to the Verkhovna Rada of Ukraine in 2020. Thus, the functions of protecting moral values should be entrusted to the Security Service of Ukraine, which is responsible for preventing and stopping crimes against the foundations of national security. The draft Law on Amendments to the Law of Ukraine "On the Security Service of Ukraine" to improve the organizational and legal framework of the Security Service of Ukraine proposes to introduce Article 3-2, according to which the objects of national security of Ukraine are proposed to recognize:

- man and citizen, namely: his life and health, honour and dignity, inviolability and security, constitutional human rights and freedoms;

- society: spiritual, moral and ethical, cultural, historical, intellectual and material values, information and environmental environment, natural resources;

- state: constitutional order, sovereignty, territorial integrity and inviolability, system of public administration [5]

As you can see, the proposals of this Project fully comply with the principles of state policy in the field of national security and defence, which in accordance with Article 3 of the Law of Ukraine "On Security Service of Ukraine" aims to protect people and citizens (their lives and dignity, constitutional rights and freedoms). safe living conditions); society (its democratic values, prosperity and conditions for sustainable development); state (its constitutional order, sovereignty, territorial integrity and inviolability); territory, environment (from emergencies [6]. Thus, the objects of national security of Ukraine logically include spiritual and moral and ethical values, the essence and content of which, unfortunately, is not defined in any legal act.

In our opinion, public morality as an object of protection by the security service of Ukraine should include in its structure values and ideas related to the life of society, as well as requirements and practices corresponding to these values. Under such conditions, morality is endowed with a defining, regulatory, evaluative and informational function. According to Art. 3 of the Law of Ukraine "On the Security Service of Ukraine" among other fundamental national interests of Ukraine is also the sustainable development of the national economy, civil society and the state to ensure the growth of quality and quality of life. It is clear that the protection of these and other interests is impossible without knowledge and evaluation of the objects of practical activity and thus the abovementioned functions of morality together determine the value segment of society. In addition, according to researchers, morality also has an educational function, which acts as a means to realize the main purpose of morality: to control human behaviour, and thus this function can not exist by itself, but is part of all other functions of morality, as if dissolving in them [7, with. 65].

Thus, as an object of national security, public morality can be interpreted in a narrow and broad sense. Thus, in a broad sense, it is a system 
of state values (sovereignty, language, territorial integrity, health, honour, dignity, inviolability of the person, etc.). In the narrow sense, the object of social morality is not only the spiritual condition of the average person, but also the officials of the national security body, because effective reform of the National Security Service of Ukraine, its stability and efficiency is impossible without new approaches to personnel and educational policy. It is not possible, for example, today within the rule of law traits that were required of employees of the Security Service of the Organization of Ukrainian Nationalists (1946) as: "the use of all means to achieve the goal" [8, p. 208].

In our opinion, the protection of morality is becoming even more valuable today, as the problem of alienation of state bodies and their officials and society must be overcome. The state approach to the protection of morality as an object of national security will thus be based on partnership principles of cooperation to ensure the national security of Ukraine, because morality as an object includes appropriate ideas about universal human values and aims to regulate social relations by defining appropriate values and rules of conduct.

It is assumed that the prospect of the development of legal science as a whole, in a democracy, will be the construction of a rule of law state through the development of civil society institutions and increasing their role in the process of interaction with law enforcement agencies, because state bodies are largely associated with the development of the problem of interaction between law, morality and power. In modern conditions, these problems can be investigated and solved by building a global moral and legal theory. The problematic place in this aspect will remain the moral level of the official themselves of the security service of Ukraine, which, like any other law enforcement agency, has always been under the scrutiny of society, since it in one way or another affects the interests of all its members and its results directly affect the security of the individual, society and the state, the implementation of their legitimate interests. Work in the security service of Ukraine is associated with many moral problems generated by its specifics and methods of achieving goals, forms, means of activity. The mere fact that to defend morality as a fragment of ensuring law and order and a quiet life of citizens with the use of measures of coercion and restriction can cause a whole complex of contradictions both in the public and in the individual consciousness.

Thus, when morality becomes an object of state protection, a clear statement of the tasks facing the security services of Ukraine, the definition of their powers, is of particular importance, and possible admissible remedies. The second problem here is the issue of moral readiness and to take on the role of "defenders of morality" by security personnel, since the protection of morality imposes on these employees an additional high responsibility for strict and accurate observance of morality. This means that we are talking about the moral "increased" requirements for the behaviour of security personnel of Ukraine.

The direction of our state towards the protection of morality, in any case, is positive and justified, and therefore, in the activities of the security services it is so important in each case to translate innovations into the language of morality, identifying only real threats, thereby showing that it is possible to adhere to the letter of the law only by permissible means, because otherwise the principles of morality are violated, meaning is lost. Justification of non-moral actions by the specifics of the activities of security service officials and the presence of many non-standard situations does not take place in a legal state, because at any 
stage of choosing a variant of action, moral motivation is always assigned a decisive role. After all, professionalism is revealed where the subject evaluates his actions not only from the standpoint of the law, but also from the standpoint of honour and morality.

Thus, morality as a specific object of the national security service of Ukraine should form a kind of code of appropriate and positive for society, regulate behaviour, have a special spiritual dimension and perform a number of socially significant functions in society that contribute to the harmonization of personality and society.

The article examines the expediency of introducing spiritual and moral and ethical values as an object of protection by the National Security Service of Ukraine in accordance with the draft Law on Amendments to the Law of Ukraine "On the Security Service of Ukraine" to improve organizational and legal principles. activities of the Security Service of Ukraine. It is established that as an object of national security, public morality can be interpreted in a narrow and broad sense. In a broad sense, such an object of public morality can be interpreted as a system of state values, such as sovereignty, language, territorial integrity, health, honour, dignity, inviolability of the person and so on. In the narrow sense, the object of social morality is the spiritual state of each individual, because a person according to the Basic Law of Ukraine is the highest value. It is clear that public morality cannot be "programmed" even by interpreting the practice of past world experience, and thus moral values are more appropriate to lay in the legal field to be protected. In our opinion, public morality as an object of protection by the security service of Ukraine should include in its structure values and ideas related to the life of society, as well as requirements and practices corresponding to these values. The current legislation of Ukraine, which is designed to protect human rights and freedoms, unfortunately, does not contain an interpretation of the concept of "morality" and "public morality". Even though everyone can understand good and evil, useful and harmful, he is also subject to his own ideas of good and bad. Under the law, a basic amount of responsibilities is created, the standard of moral behaviour necessary for the proper functioning of society. Thus, although the law cannot express the will of everyone and cannot correspond to the moral idea of justice of everyone, it is in democratic, legal states that the law creates a personal space of man, in which he harmoniously coexists with his own considerations of morality. Morality as a specific object of the national security service of Ukraine should form a kind of code of appropriate and positive for society, regulate behaviour, have a special spiritual dimension and perform in society several socially significant functions that will promote harmonization of person and society. Although the law cannot express the will of everyone and cannot correspond to the moral notion of justice of everyone, it is in democratic, legal states that the law creates a person's personal space in which he harmoniously coexists with his own considerations of morality. Morality as a specific object of the national security service of Ukraine should form a kind of code of appropriate and positive for society, regulate behaviour, have a special spiritual dimension and perform in society a number of socially significant functions that will promote harmonization of person and society. Although the law cannot express the will of everyone and cannot correspond to the moral 
notion of justice of everyone, it is in democratic, legal states that the law creates a person's personal space in which he harmoniously coexists with his own considerations of morality. Morality as a specific object of the national security service of Ukraine should form a kind of code of appropriate and positive for society, regulate behaviour, have a special spiritual dimension and perform in society a number of socially significant functions that will promote harmonization of person and society.

Key words: public morality, object of national security, human values, principles.

Горєлова В. Суспільна мораль як об'єкт національної безпеки україни: теоретико-правовий аспект

у статmі досліджуеться питання про доцільність впровадження духовних $i$ морально-етичних цінностей як об'єкта захисту службою національної безпеки України відповідно до внесеного до Верховної Ради України проєкту Закону про внесення змін до Закону Украіни «Про Службу безпеки України» щодо вдосконалення організаційно-правових засад діяльності Служби безпеки України. Встановлено, що як об'єкт національної безпеки суспільна мораль може трактуватися у вузькому й широкому значенні. У широкому значенні такий об'ект суспільної моралі можна трактувати як систему державних циіннотей, таких як суверенітет, мова, територіальна иілісність, здоров'я, честь, гідність, недоторканність особи тощо. У вузькому значенні об'єктом суспільно моралі виступае духовний стан кожної окремої людини, адже людина відповідно до Основного закону України є найвищою иінністю. Зрозуміло, що суспільну мораль не можливо «запрограмувати» навіть трактуванням практики минулого всесвітнього досвіду, й, таким чином, моральні цінності доречніше закласти в правове поле, що підлягає охороні. На наш погляд, суспільна мораль як об'єкт охорони Службою безпеки України повинна якраз містити у своїи структурі иінності й уявлення, пов'язані із життям суспільства, а також відповідні иим иінностям вимоги й практики. Чинне законодавство Украӥни, яке покликане забезпечити захист прав $i$ свобод людини, на жаль, не містить тлумачення поняття «мораль» й «суспільна мораль». Не дивлячись на те, що кожна людина здатна розуміти добро й зло, корисне ü шкідливе, вона також підкорена власним уявленням про добре ü погане. У рамках закону створюеться базовий обсяг обов'язків, стандарт моральної поведінки, необхідний для нормального функиіонування всього суспільства. Таким чином, закон хоча й не може виражати волю кожного й не може відповідати моральним уявленням про справедливість кожного, однак саме в демократичних, правових державах завдяки закону утворюеться особистий простір людини, в якому вона гармонійно уживається зі своїми власними міркуваннями про мораль. Мораль як спеиифічний об’єкт служби національної безпеки України повинна утворювати своєрідний кодекс належного й позитивного досвіду для суспільства, регулювати поведінку, мати особливий духовний вимір $i$ виконувати в суспільстві цілий ряд соціально-значущих функцій, які будуть сприяти гармонізації особи ü суспільства.

Ключові слова: суспільна мораль, об'єкт національної безпеки, людські цінності, принципи. 


\section{References}

1. Kant I. Fundamentals of the metaphysics of morality. Moscow : Mysl, 2001. $80 \mathrm{~s}$.

2. Hegel G.V.F. Philosophy of religion: In 2 volumes. T. 1. Moscow : Misl, 1976. $532 \mathrm{~s}$.

3. Fromm E. The Anatomy of Human Destructiveness. New York : Holt, Rinehart and Winston, 1973. 599 p.

4. On Protection of Public Morality: Law of Ukraine from 20 November 2003 № 1296-IV / Verkhouna Rada of Ukraine. Information of the Verkhouna Rada of Ukraine. URL: https: / /zakon.rada.gov.ua/ laws / show/1296-15\#Text.

5. Draft Law on Amendments to the Law of Ukraine "On the Security Service of Ukraine" on Improving the Organiza- tional and Legal Principles of the Security Service of Ukraine. Verkhouna Rada of Ukraine : official web-portal. URL: http: / / 1.c1.rada.gov.ua/pls / zweb2/ webproc4_1?pf3511=68347.

6. On the Security Service of Ukraine: Law of Ukraine from 25 March 1992 № 2229. XII / Verkhouna Rada of Ukraine. Information of the Verkhouna Rada of Ukraine URL: https://zakon.rada.gov.ua/laws / show/2229-12\#Text.

7. Kotov L. Methodological problems of moral progress. Sverdlousk, 1974. 163 p.

8. Materials and documents of the OUN (b) Security Service in the 1940s pp. / order. O. Lysenko, I. Patryliak. Kyiv : Institute of History of Ukraine, National Academy of Sciences of Ukraine, 2003. 256 p. 